\title{
Reversals of fortune: path dependency, problem solving, and temporal cases
}

\author{
Jeffrey Haydu
}

Published online: 16 October 2009

(C) The Author(s) 2009. This article is published with open access at Springerlink.com

\begin{abstract}
Historical reversals highlight a basic methodological problem: is it possible to treat two successive periods both as independent cases to compare for causal analysis and as parts of a single historical sequence? I argue that one strategy for doing so, using models of path dependency, imposes serious limits on explanation. An alternative model which treats successive periods as contrasting solutions for recurrent problems offers two advantages. First, it more effectively combines analytical comparisons of different periods with narratives of causal sequences spanning two or more periods. Second, it better integrates scholarly accounts of historical reversals with actors' own narratives of the past.
\end{abstract}

Between the late 19th century and World War I, San Francisco's bourgeoisie moved in succession along two opposing paths. In contrast to most U.S. cities, the trend in San Francisco from the 1880s through the 1900s was for businessmen to be divided among themselves and for a majority of employers to recognize and bargain with labor unions. This pattern reflected the cumulative effects of racial cleavages in industry (smaller employers allied with craft labor against the Chinese), the balance of class power (a powerful labor movement made collective bargaining prudent for employers insulated from national competition), and the character of business organization (most manufacturers organized by trade rather than in more inclusive civic organizations). Between the early 1910s and the 1920s, however, the pattern switched. Employers increasingly rallied together, particularly in opposition to unions. In the early 1920s, they finally purged unions from such strongholds as metal working and construction, replacing collective bargaining with the open shop (Haydu 2008).

J. Haydu ( $\square)$

University of California, San Diego, La Jolla, CA, USA

e-mail: jhaydu@ucsd.edu 
San Francisco's reversal dramatizes a general dilemma for historical sociologists dealing with successive historical periods. On one hand, we may want to compare the two periods to help identify the causes of divergent outcomes. On the other hand, we may be interested in how characteristics of the first period influence the next, or how the events of these two periods together form a larger sequence. The first goal treats the two cases as independent; the second highlights their connections. How can we have it both ways?

In the first part of this paper I spell out the problem in greater detail, using as a counterpoint methodological approaches that, for one reason or another, do not recognize that there is a problem. The second part turns to an explanatory model that is widely recommended for demonstrating both the influence of the past on the present and the importance of sequences of events: path dependency. That model usefully alerts us to contingencies that may have steered a given case (such as a political regime or an educational institution) in a direction different from that taken in another, similar case. But when we are dealing not with two cases but with two periods, path dependency becomes more of a hindrance than a help. The third and fourth sections build on a different approach, introduced in an earlier paper (Haydu 1998). This explanatory model treats successive periods as contrasting solutions to recurrent problems. It is better suited than path dependency for combining analytical comparisons of different periods with narratives of causal sequences spanning two or more periods. It also highlights links between scholarly accounts of historical reversals and social actors' own narratives of the past. A final section applies this model to the puzzle of bourgeois class formation in San Francisco.

\section{The problem of historical reversals}

The general question raised by San Francisco's reversal is how best to account for both differences between time periods and larger trajectories. The answer is not obvious. Accounting for differences involves periodizing, dividing San Francisco's history into separate eras and comparing the two with an eye to explaining those differences. Such temporal comparisons are a useful complement to other strategies for identifying causal relationships, such as process tracing, event structure analysis, and small $n$ comparisons of other cases. But they entail the fiction that two periods, such as San Francisco before and after 1911, represent independent cases. Accounting for larger trajectories, by contrast, sees these cases as part of a longer, coherent sequence of events, one in which the influence of earlier developments on later ones spans periods. Far from treating the periods as independent cases, identifying larger trajectories means showing how one "case" becomes another.

The methodological tension between these goals arises for any two (or more) periods. It is particularly obvious when the periods involve a reversal in the "dependent variable" - when the conditions or outcomes of interest are not merely different but in some sense opposites. San Francisco illustrates a reversal in class formation, a period of fragmentation followed by a period of solidarity. There are many other examples. Until the early 1980s, most observers saw an expansion of state intervention - economic regulation, welfare provision, state enterprises - as the norm for advanced societies. Over the next twenty-five or more years, the challenge 
was to account for varying patterns of deregulation, welfare retrenchment, and privatization (Starr 1990). For much of the 20th century, the standard model for manufacturing involved top-down control, specialized production equipment, and narrowly trained task workers. Beginning in the late 1970s, management gurus and academics celebrated a trend towards decentralized organization, versatile technology, and broadly skilled workers (Piore and Sabel 1984; Haydu and Lee 2004). Carlos Waisman describes Argentina's balanced and rapid economic development until the 1930s and compares it with the country's protracted stagnation and underdevelopment thereafter (Waisman 1987). And some jobs that employees and employers alike defined as masculine, and from which they excluded women, later became feminized (Reskin and Roos 1990). In none of these examples does history simply return to some earlier point. But in each, the explanatory goals for the two periods appear at odds. How are we to combine explanations for fragmentation, statism, deskilling, economic development, and male monopoly in one period with explanations for solidarity, privatization, upgrading, economic stagnation, and feminization in the next?

One way to flesh out the problem is by way of contrast to methodological approaches that would reject the premises of the question. For an old-fashioned historian, the mistake is to have thought of the two periods as two cases of the same thing. Each should instead be explored on its own terms, without any assumption that the character or dynamics of one era will be found in another and without imposing any overarching narrative on the two. At the other extreme, positivists who define causality in terms of covering laws would find the question wrong-headed for a very different reason. To the extent that scholars had predicted trends towards fragmentation, deskilling, and so forth, subsequent events clearly proved them wrong. In effect, these scholars committed a sampling error, examining a slice of time too short, a temporal $n$ too small, to reveal the typical outcome. The solution is not and should not be to develop two explanations, one for outcome A and one for the opposite of A. Instead, the answer is to increase the sample size or abstract from the historical details until a general pattern has been identified. These average outcomes or general patterns can then be properly explained. ${ }^{1}$

A more common approach to the past among sociologists is "variable based" (Abbott 1992; s.a. Sewell 1996b, on "experimental time"). Like the old-fashioned historian, variable-based sociologists welcome periodization; like the devotee of covering laws, they aim for causal generalization. They combine these by treating two periods as separate cases and identifying independent variables which correspond to the contrasting outcomes. One example of how this approach looks when applied to historical reversals is Christopher Einolf's account of state torture in western societies. Resort to torture declined over the 18th and 19th centuries, Einolf argues. Yet the reasons commonly offered for this trend, such as changes in moral sensibilities or legal standards, cannot explain the trend's reversal in the 20th

\footnotetext{
${ }^{1}$ I take this to be the recommendation of Kiser and Hechter (1991) in their discussion of how to evaluate the relationship between state autonomy and state policy: define "state autonomy" broadly enough to encompass most societies at most times, and use that broad range to identify invariant causal laws. As the response to Kiser and Hechter shows (for example, Quadagno and Knapp 1992; Somers 1998), many historical sociologists neither define "explanation" in terms of general laws nor discount so heavily the significance of historical detail.
} 
century. Einolf demands a single causal account which can "predict the use of torture across societies and time periods" (Einolf 2007:102). He believes that two factors meet this requirement: the numbers of people who are not recognized as full members of national societies and the perceived threat to the state posed by individuals. These account for both the fall and subsequent rise in torture, as a period of extended citizenship rights gave way to one characterized by new types of war and new types of state. ${ }^{2}$ Einholf may well be right. His variable-based approach, however, rules out the possibility that the causes of torture's fall in one period and rise in the next may be different. And treating the two periods as independent cases forecloses more complex accounts. For example, the spread of particular models of citizenship to new regions may have done more than reduce the incidence of torture; it may also have led to frictions between regimes that would later foster new types of war and state. A similar logic can be seen in one major part of John Foran's explanation for "reversed revolutions." In cases where revolutionary movements gained political control but then lost it before implementing significant social changes, the implicit contrast is between the period leading up to revolution and the (brief) period from revolutionary victory to fall from power. In the cases Foran examines, one key variable - opportunities created by the country's position in the world system - obligingly switches from open in the first period to closed in the second. ${ }^{3}$ Here too, the explanatory model draws attention away from events and choices which may have contributed to revolutionary reversals in one case but not in another.

Historically-minded sociologists find much to fault in variable-based treatments of history. Some of their criticisms do not focus specifically on the comparison of time periods. One such criticism is that variable-based accounts fail to capture the nature of historical causation. If one agrees with Andrew Abbott that "social reality happens in sequences of action located within constraining or enabling structures" (Abbott 1992:428), then causation involves the interaction of actors and events over time, not the immaculate operation of variables. And by filtering out unpredictable events and human causal agents, variable-based accounts underestimate the role of serendipity in historical outcomes. Particular outcomes, the critique continues, are better explained through narratives in which actors and events are placed in temporal as well as structural context and in which their interaction is ordered into causal sequences.

Where scholarly investigations cover two or more periods, variable-based treatments of those periods as distinct cases suitable for comparison are not without merit. They offer historical sociologists working with a small $n$ some additional leverage for refining concepts and checking hunches about causal relationships. But they should be used with caution. Even if one accepts the logic of sorting social life into independent and dependent variables with consistent relations between them, there are two obvious flaws in treating successive periods as if they were separate

\footnotetext{
${ }^{2}$ Steinmo's analysis of British tax policy traces a series of reversals, with progressive and regressive formula trading places as party power shifted between Labour and Conservatives (Steinmo 1993). I am indebted to Isaac Martin for this example.

${ }^{3}$ The second major part of Foran's account follows, instead, the logic of covering laws. Successful revolutions require a "political culture of opposition." The requisite oppositional cultures are found in both enduring and reversed revolutions, but they are stronger in the former than in the latter (Foran 2005).
} 
runs of an historical experiment. First, there is the dubious assumption that causal relations which hold in one period will hold in another. Relinquishing that assumption of causal uniformity has a clear benefit for understanding historical reversals: they may reflect not the shifting value of some variable in a consistent causal pattern, but instead the rise of an entirely different causal regime (Isaac and Griffin 1989; Abbott 2001:291). Second, variable-based comparisons of time periods could stand on their own only if the cases were both equivalent and independent. Although successive time periods may be more equivalent than two national cases, they are certainly less independent. More importantly, it is precisely the ways in which events and outcomes in one era influence those in another that interest many historical sociologists, and that interest cannot be served by treating periods as independent cases. Thus the question remains: how can we both compare periods and combine them into larger trajectories in which the past influences the present through causal sequences?

\section{Path dependency to the rescue?}

Path dependency is a commonly recommended model for capturing both the influence of earlier times on later ones and the importance of sequence in social causation. Path dependency is a particular kind of narrative, or a particular metaphor for guiding the construction of narratives. As in any other narrative, it organizes events and circumstances into temporal sequences. These become explanatory sequences by identifying critical junctures which foreclose options and steer history in one or another direction (David 1986; Arthur 1988; North 1990). The narrative begins with an historical fork in the road, identifies the turn taken, and emphasizes how subsequent developments make that choice irreversible. Michael Piore and Charles Sabel, for example, point to alternative methods for organizing industrial manufacturing in the early 20th century. Once American business adopted mass production rather than flexible specialization, industrial technology followed a developmental course from which departures became increasingly difficult (Piore and Sabel 1984). Kim Voss identifies a turning point in American working-class politics in the late 1880s. At that time, the defeat of the Knights of Labor eliminated the institutional infrastructure and ideological visions which had supported class solidarity. The labor movement subsequently proceeded along tracks laid down by the sectional organization and business unionism of the American Federation of Labor (Voss 1993).

The term "path dependency" is often applied loosely to any claim that historical options or causal relations are constrained by prior developments. But it is the more specific arguments about turning points and lock-in mechanisms that make path dependency something more than plain historical common sense. What sets path dependency apart is not so much the way it describes historical change as the way it explains those changes. When accounting for historical turns down one road rather than another, path dependency emphasizes contingency. In Paul David's classic account of the QWERTY typewriter keyboard, designers had to locate keys in positions that, while awkward for typists, minimized jams in the early machines. By contrast, to explain subsequent continuities, path dependency offers an account 
which is highly deterministic. Here, the emphasis is on mechanisms which reproduce the outcome of an historical turning point, making movement off the path increasingly difficult. Although improved typewriters largely solved the jamming problem, by then sunk costs in human and infrastructural capital had locked in the QWERTY design (David 1986).

Unlike variable-based contrasts between periods, then, path dependency allows for causal heterogeneity. The general mechanisms which lock in historical paths may have much in common from one case to another. It will often be possible to identify the general role of sunk costs, human capital, coordination effects, and the power of history's winners in reinforcing institutional arrangements (Arthur 1994; Goldstone 1998; Pierson 2004). But the particular character and relative weight of different inertial forces will certainly vary from one period to another. Path-dependent narratives also assign due weight to events. Indeed, the causal account of which path history takes turns on the timing and sequence of events at critical junctures, not on the operation of variables. What mattered for the QWERTY keyboard was when technicians solved the problem of jamming (too late to switch to a more efficient keyboard layout). What mattered for northern Italy's effective democratic government in the 20th century, Robert Putnam argues, was that region's longer experience with communal self-regulation in the 12th-14th centuries, as compared with the south (Putnam 1993). ${ }^{4}$ And because the metaphor of path dependency highlights the importance of timing and events at the outset of trajectories, it draws attention to the role of contingency in history. Deterministic influences may keep history on track, but switchpoints are moments of serendipity (Mahoney 2000). Isaac Martin's (2008) interpretation of US tax protest since the 1970s traces popular grievances back to the rationalizing reforms of local assessors, who began to withdraw customary allowances that had kept property taxes down despite soaring home values. Progressive as well as conservative proposals were offered around the country to address these grievances. As it happened, the first major proposal to pass by referendum was California's Proposition 13, a conservative measure stressing tax limitation rather than tax equity. That campaign's successful call for "tax relief" was quickly taken up as Republican orthodoxy, and evidence of popular support for the measure altered the calculations of even Democratic politicians, crowding out progressive alternatives. Thus did a happenstance of timing lead to a "permanent tax revolt."

Champions of path dependency, then, endorsed the move to replace independent and dependent variables with narratives in which sequences of events lead to specific historical outcomes. In principle, that move to narrative explanation has much to recommend it (Abbott 1992; Somers 1992; Griffin 1993; Gotham and Staples 1996). And in practice, path-dependent accounts have been valuable for explaining differences between cases, such as contrasting patterns of state formation (Ertman 1997; Mahoney 2001), working class politics (Voss 1993), and welfare policy (Pierson 1994; Orloff 1993). But problems arise when the cases for comparison are successive time periods rather than trajectories in different places. Path dependency's peculiar way of blending contingency and causality when depicting the influence of

\footnotetext{
${ }^{4}$ As Sabetti (1996) shows, the elegance of such path-dependent accounts is no guarantee of their reliability, however.
} 
the past on the present makes it harder to construct explanatory sequences that encompass two or more periods. On one side, narratives of path dependency strongly emphasize the contingent, unpredictable character of the historical events that start a path. James Mahoney is unusually explicit that at the outset of a new trajectory there is a break in historical causation: path dependence "involves both tracing a given outcome back to a particular set of historical events, and showing how those events are themselves contingent occurrences that cannot be explained on the basis of prior historical conditions" (Mahoney 2000:507-508). On the other side, once contingent events steer history towards a specific outcome, path-dependent accounts highlight the many forces that reinforce that outcome. Thanks to "increasing returns," "positive feedback," institutionalization, and other lock-in mechanisms, it becomes increasingly difficult to switch paths. Kathleen Thelen has criticized path dependency for thus exaggerating both the undetermined nature of junctures and the overdetermined character of trajectories (Thelen 1999; see also Haydu 1998). It should be added that this exaggerated contrast between serendipitous switchpoints and locked-in paths makes it more difficult to show the importance of sequences of events and the corresponding influence of the past - supposedly path dependency's strong suits - when more than one period is involved. Because the switch-point is a moment of contingency, when unpredictable or exogenous events channel history in new directions, the model introduces a sharp break between paths, with no obvious mechanisms for conveying the influence of one period into the next. And because of the emphasis on increasing lock-in over time, such that paths are normally reproduced, it is hard to accommodate sharp changes in direction. Where historical changes are seen as becoming irreversible over time, it is especially difficult to explain historical reversals.

There is another reason that path dependency is handicapped in dealing with historical reversals. For all its good work in teaching sociologists that history matters, path dependency offers only a single- and simple-minded understanding of time. When history changes course - as when fragmentation gives way to solidarity among San Francisco businessmen - there are at least two explanatory challenges. One is to show, as Marx might say, how new possibilities were developing within the womb of the old regime. The organizational basis for bourgeois unity did not appear abruptly in 1911. It can be traced back to civic associations founded more or less in the middle of the period of fragmentation. These associations did not enroll a large and broadly representative group of businessmen until after 1911, but their earlier history would have to be part of the narrative account of bourgeois class formation. Here, then, is a more complex temporality than path dependency imagines: two separate and even contradictory "paths" overlapping in time. The second explanatory challenge is to show how multiple such paths, each with its own temporal rhythm, coincided to effect change (Sewell 2005:ch. 9).

Path dependency, with its serendipitous switchpoints, is of little help in thinking about how these distinct causal trajectories were brought together. In San Francisco, the turn towards bourgeois unity in the 1910s reflected not only organizational developments among businessmen, but also longer-term shifts in race relations and shorter-term opportunities created by the San Francisco earthquake and by the labor movement's withdrawal from independent electoral politics. The passive voice of "were brought together" offers a clue to an alternative. One solution to these two 
explanatory challenges is to give historical actors a more prominent narrative role in the temporal alignment and realignment of multiple paths.

\section{An alternative: sequences of problem solving}

Putting actors at center stage is a preferable methodological approach when the task is to link and compare successive time periods. One way to do so is to distinguish epochs as successive problem-solving regimes rather than marking them off on the basis of distinct path-dependent trajectories (Haydu 1998). The analytical starting point is recurrent dilemmas faced by social actors. Employers of wage labor typically seek to maximize productive effort while keeping conflict within boundsakin to the problem identified by Michael Burawoy of "securing and obscuring surplus value" (Burawoy 1979). Political elites, Reinhard Bendix (1978) argued, have long wrestled with the problem of justifying rule by the few over the many. George Fredrickson $(1988,1997)$ builds much of his comparative work around the problem of labor control confronting plantation owners before and after emancipation. Dilemmas such as these underlie important continuities over time. In contrast to path dependency, they focus attention on, rather than diverting attention from, the links between successive periods. Periods differ, however, in the characteristic solutions devised by social actors for the problem at hand, thus setting up the empirical question of why certain solutions rather than others are pursued at particular times. The answers may invoke serendipitous influences and may be subject to "positive feedback," as in path dependency. But they also may be prone to breakdown, whether out of internal contradictions, incompatibility with new circumstances, or shifts in the balance of power among proponents of rival solutions. Making actors the "strategic pivots" (Kimeldorf 1988) of problem solving not only helps identify analytically useful periods. It also provides a mechanism through which multiple causal trajectories - such as fleeting political opportunities, slowermoving changes in economic resources or strategic allies, and long-standing cultural repertoires - are brought together in episodes of social transformation. ${ }^{5}$

This is a methodological strategy, not a substantive claim about the role social actors play in history. Narratives of problem solving, like narratives of path dependency, are guides to research as well as plotlines for the stories we eventually tell in publications. The metaphor of path dependency tells us to took for serendipitous events that, during critical periods, turn history down one path rather than another. The image of reiterated problem solving tells us to look for some combination of changes in challenges, resources, understandings, and opportunities that lead actors to take new approaches to recurrent dilemmas. This methodological guideline carries no assumption that these actors have the autonomy to make a difference in historical outcomes. Yet even if they are tightly constrained-facing a crisis too severe to ignore, slavishly accepting conventional diagnoses of a problem, confronting an array of social pressures to respond in a particular way-centering the account on these actors still enables us to trace the roles of ruptures in the old

\footnotetext{
${ }^{5}$ Rhomberg (2004) adds the further complexity that these actors may themselves be changing, as in the successive social movements that contested municipal regimes in Oakland.
} 
order, inherited cultural frames, and institutional constraints on what happens next. Historical actors, moreover, may not define the problem in the same terms as academic observers: most American employers probably have never heard of "surplus value." But there must be some way of translating scholarly categories into the practical dilemmas experienced, recognized, and grappled with by real people. Insisting on this correspondence checks sociologists' theoretical flights of fancy and directs our attention to points for which we need to gather evidence. It also establishes two key links. One is between historically distinct periods (regimes of problem solving) and larger trajectories spanning those periods (tied together by recurrent dilemmas of action); the second is between multiple causal trajectories producing change.

An intellectual strategy such as this is nicely illustrated by Jeffrey Paige's (1997) complex account of coffee elites and political regimes in Central America. Paige's main concern echoes Barrington Moore's. What are the historical routes to dictatorship and democracy? The question clearly lends itself to a path-dependent explanation, and there is much in Paige's narrative that could be recast in those terms. But Paige builds his analysis around collective actors - the producers and processors of coffee - who face the standard dilemma of economic elites, namely how to secure a political regime compatible with economic exploitation. In so doing, he is able to accomplish two things that elude path-dependent accounts. He shows the convergence of several independent historical trajectories at critical junctures, and he shows the cumulative causal impact of successive periods of crisis and restabilization. For each of his three main cases, he follows the link from class to politics through consecutive periods, beginning in the mid-19th century. The key periods are inaugurated by crises, the insurgences of the 1930s and 1980s. The outcomes of those crises, in turn, are shaped by the conjuncture of economic, political, and ideological influences, each of which have partly independent histories. It is the coffee elite that brings these influences together and gives them causal force.

At the first switchpoint, in the 1930s, inherited class relations and elite culture came together with global economic depression to produce novel patterns of insurgency, political restabilization, and ideological change. Prior class relations combined with severe economic hardship led insurgency towards communist mobilization in El Salvador, more social democratic opposition in Costa Rica, and nationalist revolt in Nicaragua. Political and ideological outcomes reflected in part these different challenges faced by coffee elites - elites who were themselves shaped by prior patterns of development. Restabilization in El Salvador and Nicaragua required military repression, but El Salvador's powerful and unified coffee elite maintained close ties to the regime. Their Nicaraguan counterparts, by contrast, saw their modest political influence further curbed by Somoza's personalistic dictatorship. Costa Rica's less radical insurgency and its coffee elite's more influential liberal wing permitted a relatively democratic outcome. Alongside these regime changes, finally, were ideological shifts in which coffee elites, responding to different challenges with different resources, selectively elaborated different strands of the liberal tradition. El Salvador's elites celebrated "progress," depicting themselves as the agents of economic development which would benefit all. Nicaragua's coffee elite, its power limited and its interests ill-served by Somoza, 
championed bourgeois "liberty"-freedom from state controls and freedom to make money. Coffee elites in Costa Rica, finally, proclaimed the nation's exceptionalism as a "democracy" based on a largely mythical economy of small and equalitarian producers.

The 1980s marked another historical switchpoint, with the narrative fruitfully complicated by the conjuncture of multiple causal trajectories and legacies left by the resolution of the 1930s' crises. By the 1980s, changes in the labor process within coffee production had enhanced the power of the agro-industrial wing of the coffee elite, and thus the openness of the elite to democratic reforms. Outside the coffee sector, industrialization had also increased the numbers of urban workers in popular insurgency, particularly in El Salvador and Nicaragua. These developments, combined with inherited differences in the unity and political position of coffee elites, reconfigured patterns of insurgency and elite strategies of social control. El Salvador's elite, closely allied to the military regime and defining unrest as a communist conspiracy, resorted to harsh repression. Substantial numbers of Nicaragua's agro-industrial coffee elite, shut out of power and ideologically committed to "liberty," joined the Sandinistas against Somoza, even though revolution jeopardized their material interests. Yet by the end of the decade, longterm changes in class relations and the evident failures of El Salvador's military dictatorship and Nicaragua's socialist regime set the stage for historical reversals. In both cases, agro-industrial elites gained strength and recognized the costs of repression and insurgency. In El Salvador they joined industrialists in pushing for a negotiated settlement; in Nicaragua they abandoned the socialists but also tempered the conservatism of the contras. The upshot was movement towards more democratic political regimes and neo-liberal ideologies.

Had Paige blurred the complexities of these stories and collapsed multiple periods into a single narrative, he would have produced a much shorter book, and a much less interesting one. He could have contented himself with a simple causal claim and a modest amendment to Moore's thesis: the rise of industrial capital, combined with threats from below, leads to democracy. Instead, he shows how varied were the routes from there to here, with outcomes at different times shaped by the organization of production, the state of the world economy, the nature of political opportunities, and the character of popular unrest. And the way he is able to integrate those multiple causal streams - as they converged in particular periods and as they handed down constraints and resources from one period to the next-is by organizing his account around class actors seeking profits and stability.

At first glance, James Mahoney's (2001) study of Central American political regimes, overlapping in cases and concerns with Paige's, appears to present a more conventional path-dependent account. The most general story it tells is one of a single critical juncture, the late-19th to early-20th century reform era. At the start of this period, Mahoney argues, each of his five cases might still have gone in relatively democratic or authoritarian directions. It was the character of liberal reform in each case, not prior differences between cases, that determined their fates. Radical liberalism pushed El Salvador and Guatemala towards a militarized state and polarized agrarian class relations, reformist liberalism steered Costa Rica towards democracy, and aborted liberalism led Honduras and Nicaragua towards authoritarianism. These were moments of contingency, shaped by immediate political 
circumstances or outside intervention, with outcomes that could not have been predicted by antecedent conditions.

So far, the comparison offers an ideal setting for a path-dependent account. Mahoney's focus is on a single point of divergence among multiple cases, and he presents those cases as similar enough that prior conditions did not rule out alternative future regimes. It thus makes good sense to suspect that certain contingent events and choices at this historical point determined the course of regime development. Like other good comparativists, however, Mahoney urges us to complement cross-national comparisons with in-depth examination of individual cases in order to check causal claims (Mahoney 2004; Bennett and Elman, 2006). As he does so, the indeterminacy of the critical juncture recedes. Mahoney makes clear that neither the character of the problems faced by political leaders in the reform period, nor the choices they made in response, were detached from prior conditions in each country. Those prior conditions do not fully explain outcomes, but in this they are no different from any other historical influence. Above all, more advanced commercialization of agriculture and greater state capacity gave elites in Guatemala, El Salvador, and Nicaragua policy options not enjoyed by their counterparts in Costa Rica and Honduras. In Costa Rica, on the other hand, the combination of weak landlords and a weak military made gradual commercialization and state-building "extremely likely" (p. 146). In addition, long-standing conflicts between liberals and conservatives were among the critical challenges to which reform-era political elites responded - as best they could, given the constraints and opportunities presented by agrarian relations and government institutions.

There are, of course, substantive differences between Paige's and Mahoney's accounts, particularly in their relative emphasis on class versus political dynamics in regime development. But the differences in their accounts are also related to their respective methodological approaches. In Mahoney's work, the narrative of path dependency separates across-case contingencies from within-case continuities. It is through comparisons among cases, highlighting similar outcomes across different (in some ways) cases and different outcomes among similar (in some ways) cases, that Mahoney makes the argument for the importance of contingencies: antecedent conditions cannot explain the later paths. The continuities, by contrast, are revealed through closer looks at each country's history over longer periods of time. Paige, focusing on more than one period of crisis and restabilization, makes contingencies and continuities part of a single narrative. And by organizing his account around problem-solving actors, Paige naturally pays far more attention to their corporate ideology. Doing so gives him still more ways to track the influence of the past at critical junctures and to trace the legacies of those switchpoints in subsequent periods.

One of the main advantages of the problem-solving approach is to let the observer have his cake and eat it too. He can ask "variable-based" historical questions - why did actors adopt these problem-solving strategies rather than other plausible ones? What were the effects of strategies in this period as compared to those in another period? - using, among other methods, Millian or boolean comparative techniques. For this purpose, the observer falls back on the familiar fiction of independence between cases. But the central narrative role of recurring dilemmas, and the emphasis on how "independent variables" in the second period are passed down 
from the first, make it clear that these cases are part of a more encompassing sequence. John Walton's (1992) study of "water wars" is illustrative. He divides Owens Valley struggles for local autonomy into three distinct periods. They are tied together both by the underlying problem of resisting expropriation by Los Angeles and by the ways in which struggles in one period bequeath organizational and rhetorical repertoires to the next. Thus the environmentalist movement against Los Angeles water policies in the 1970s made use of an earlier language of "the rape of the valley" and still older strategies of mobilization through citizens' committees. But Walton also distinguishes the three periods in more variable-based terms. Most importantly, he compares the breadth and the success of mobilization against Los Angeles. How broadly based was the resistance? What legal victories were won? What compromises were forced on Los Angeles officials? He can then ask what "independent" variables, such as the nature of political opportunities and the cultural framing of the valley's interests and enemies, shaped popular mobilization and political outcomes. As Walton describes his cake, he can "compare causal explanations of movement outcomes in one period with those of another [even] when later conditions include earlier results - when, that is, the events compared are not independent" (Walton 1992:242).

\section{Paths vs. problem-solving regimes in the study of historical reversals}

Both path dependency and problem-solving narratives depict history as proceeding from critical junctures to more or less durable regimes. But thinking in terms of recurrent dilemmas and mutable solutions corrects a basic imbalance in path-dependent accounts. On one side, it restores history to critical junctures, directing attention to the ways in which past sequences shape the switchpoints that separate them from future paths. It thus avoids the tendency of path dependency to underdeterminism in accounting for new trajectories. On the other side, it reminds scholars that historical paths may be more problematic than they seem - more plural, more overlapping, more open for social actors to retrospectively rearrange their itineraries. Thinking in terms of reiterated problem solving thus corrects the tendency of path dependency to make historical trajectories overdetermined, with outcomes increasingly locked in over time. Shifting the balance towards more constrained switchpoints and less deterministic paths has value in linking any two successive paths, but those advantages are particularly clear when dealing with historical reversals.

\section{Putting history back into switchpoints}

Narratives of path dependency properly highlight the role of serendipity in setting initial paths. However, by drawing a sharp contrast between eventful and underdetermined switchpoints and the deterministic mechanisms which lock in specific outcomes, they also detach switchpoints from prior history. Critical junctures and the first, tentative steps along a new path are likely to reflect the past in at least two ways highlighted by narratives of problem solving. Prior regimes foster and shape the crises that prepare the ground for new solutions, and they influence the choices made by actors in response to those crises. 
Historical reversals, like important switchpoints more generally, imply the breakdown of some institutional arrangements and their replacement by new ones. But that breakdown is unlikely to be either entirely unpredictable on the basis of past history, or an exogenous shock out of the blue. Instead, prior problem-solving regimes continue to influence later paths by fomenting the crises that separate the two. The institutions that embody routine ways of handling social problems are themselves likely to be contradictory, as students of American political development have emphasized. They have been built in fits and starts, out of disparate cultural and organizational materials, by past actors with conflicting interests and resources, exposing later incumbents to divergent rules and pressures, and are thus prone to "abrasion" and occasional failure (Orren and Skowronek 2004; Schneiberg 2007). And even if institutions were not characterized by such "intercurrence," they may be in tension with other institutions, sowing the seeds for later crises (Crouch and Farrell 2004). Thus, in Pavla Miller's (1998) sweeping account of long-term changes in patriarchy, the "patriarchalist" regime constructed in early modern Europe provided temporary stability on the basis of a nested pyramid of male authority in the family, the guild, the estate, and on up to the political monarch. But embedded in that regime were tensions between the male heads of the family and the state. These (and other) contradictions would precipitate later crises and, in turn, prompt efforts to construct new forms of patriarchal order which separated rather than fused private and public spheres. Tim McDaniel's (1991) theory of "autocratic modernization," similarly, highlights incompatibilities between autocratic rule and industrial modernization. For example, industrialization tends to undercut claims to divine authority on the part of autocratic rulers, while the personalistic and arbitrary authority of the latter blocks the emergence of groups and institutions that could help stabilize industrial capitalism. Such contradictions in the project of autocratic modernization planted the deep historical roots of revolutionary crises in Russian and Iran - roots that McDaniel offers in explicit counterpoint to more eventful and contingent sources of revolution (such as war and political mayhem in Russia). Those contingencies may, as in path-dependent accounts, shape the direction of historical developments out of a period of crisis. But to neglect the longer-term origins of the crisis is to impoverish explanations for historical change from one period to the next.

It is one thing for contradictions in one period's institutions to foster crisis; it is another for them to shape what form that crisis takes, and thus more directly influence the starting point of the next path. One way in which they may do so is to define particular points of vulnerability, to etch the lines along which old regimes may fracture. In my own comparison of patterns of restabilization in the era of World War I (Haydu 1997), the character of prewar industrial relations was an important determinant of the wartime crises that state managers had to solve. The prevalence of open shops in the U.S. put issues of union recognition at center stage during the upsurge in wartime labor militancy. Industry-wide trade agreements in Britain, by contrast, had their own weak link in the status of shop stewards, making union control over workplace representation a priority for wartime officials. As Stephen Skowronek and Karen Orren note, interpretations such as this blur the distinction between endogenous and exogenous sources of critical turning points. "Responses to exogenous shocks are themselves informed by structures, identities, cleavages, [and] 
programs ...present in the prior period" (2004:103). Weimar Germany offers one example. From late 1918 through mid 1919, workers' councils posed serious threats to employers' industrial authority and political power. In this crisis, leading employers abandoned their traditional opposition to trade unions: both formal agreements and constitutional reforms gave unions authority over workplace representation and collective bargaining (Feldman 1966; Maier 1975; Haydu 1997). These reforms solved economic elites' immediate problems. Politically, the works council system undercut a crucial base for left-socialist challenges to the SPD and the government. In the economic arena, it helped defeat the council movement's threat to union control and contributed to a short-lived moderation of industrial conflict. But this accommodation, backed by constitutional provisions on works councils, was highly vulnerable to "exogenous" economic shocks. What had been a cure for instability which served employers well in the aftermath of WWIstate-mandated union authority-became an albatross with the onset of economic depression. And given the tight linkage between industrial relations and the Weimar constitution, conflict with labor fueled political crisis. Ultimately business leaders could only resolve their economic dilemmas by reversing the Weimar republic's short-lived democratic "path" (Abraham 1981; Jones 1988).

Crises fostered by prior solutions for social problems, then, are one way old paths help steer new ones. Another is by shaping the choices actors make during those crises. Legacies of prior paths shape these choices in at least two ways: through the limits they impose on actors and through the frames actors use to interpret events and imagine alternatives. Students of labor movements have long considered how activists' choices at critical junctures are shaped by opportunities opened up and closed off by political institutions, employer practices, labor markets, and potential allies. Here too, narratives of path dependency would rightly emphasize that the events to which activists respond may be unpredictable, and thus early path development has a contingent character. But it is a mistake to highlight this side of the story at the expense of inherited constraints on actors' options. For example, with the rapid growth of the Knights of Labor in the 1880s, American workers appeared to display broad class solidarity and a close interest in local political action (Voss 1993; Gerteis 2007). By the end of the 1890s, these developments had been reversed. In place of the Knights, the American Federation of Labor dominated the labor movement, institutionalizing craft solidarity and spurning political action. Why? One interpretation highlights the crisis of the late $1880 \mathrm{~s}$ and early $1890 \mathrm{~s}$, when American labor faced withering attacks by employers. In labor's response to those challenges, however, both political and class-based strategies were forestalled by America's legal system. As William Forbath and Victoria Hattam document, the courts consistently overturned labor legislation and selectively targeted sympathetic strikes and secondary boycotts with injunctions (Forbath 1991; Hattam 1993).

The inherited cultural lenses through which actors view events also shape their choices during critical junctures. Consider a relatively microscopic example of how the serendipity of even "accidental" events should not be detached from prior history. On February 23, 1848, a crowd gathered in front of France's Ministry of Foreign Affairs to demand political reforms. As they faced a line of troops, an accidental discharge of a rifle led nervous soldiers to open fire, killing fifty protesters. Mark Traugott credits the event as "one of those incidents that suddenly 
transforms reformist protest into hardened resistance" (Traugott 1985:15), implying that either of those historical outcomes was still possible. A path-dependent account would find this a congenial example. The initial shot was serendipitous. Yet it turned a fluid state of popular opinion from reform to revolution. The subsequent consolidation of popular organization and more radical demands - a short-lived path, to be sure - could be explained in terms that have nothing to do with an accidental gun shot. But it is a mistake to treat the rifle shot as a moment of contingency isolated from past and future. Making actors the strategic pivots of historical conjunctures allows a richer account. On one side, the past shaped the "accident." Soldiers, however apprehensive in the face of an angry crowd, also probably had reason to think the worst and interpret the shot as the beginning of "mob violence." Among members of the crowd, similarly, accumulated mistrust of and grievances against the state-including its use of troops - favored particular interpretations of the troops' behavior. On the other side, the contingent event became one among many lock-in mechanisms. The massacre remained a resonant part of Parisian workers' collective memory, motivating and justifying on-going political choices. The weight of inherited cultural frameworks on choices made in times of crisis is also clear in Carlos Waisman's (1987) account of Argentina's reversal in the 1930s. The switch from economic development and liberal democracy to sluggish growth and illiberal government turned in part on the "exogenous" impact of world depression and resulting domestic social unrest. But in responding to those difficulties, political elites were guided by an inordinate and, Waisman shows, mostly illusory fear of revolution. That fear, in turn, reflected the elite's European roots and reference points as well as the immigrant history of Argentina, with the wide gap it created between an Hispanic elite and a largely Italian working class. Misdiagnosis of the threats they faced led elites to adopt policies of economic protection and corporatist cooptation, and these were the proximate causes of Argentina's reversal.

As this example reminds us, problem-solving narratives need not assign actors an independent role in directing historical change. Actors' options may be few and their choices bound. The value of this type of narrative lies more in its suggestive plot line. We are encouraged to track the convergence, through social actors, of emergent crises, institutional constraints, and cultural frames in transformations from one period to another. Narrating successive periods in this way does, however, have clear implications for how we think about seemingly deterministic historical paths.

Putting actors back into paths

If narratives of path dependency understate historical constraints at turning points between paths, their catalog of lock-in mechanisms seems to put subsequent developments on a single, irreversible track. Critics have noted this bias towards stability and determinism (Bridges 2000; Crouch and Farrell 2004) without making clear what alternative narrative techniques should guide longitudinal analysis. ${ }^{6}$ Thinking in terms of sequences of problem solving, by assigning a central methodological role to social actors, keeps alive possibilities for altering paths. It does so in one obvious way, in

\footnotetext{
${ }^{6}$ For a demonstration of how sources of dynamism can be built back into path-dependent institutionalist accounts, see Thelen (2004).
} 
which actors exploit the contradictions and opportunities discussed above. It also does so in a less obvious way, in which actors reconfigure trajectories from past to future.

I argued that past paths influence turning points through institutional vulnerabilities and social contradictions that foment and shape crises. These vulnerabilities and contradictions hardly disappear between crises, and they provide opportunities for resourceful actors to modify paths. This possibility has been explored by neoinstitutionalists, who call attention to the ways in which social movements can exploit tensions between institutional scripts to advance their causes. Elisabeth Clemens documents the early-20th-century women's movement's successful use of a maternalist script, rooted in family roles, to legitimate their call for political suffrage (Clemens 1997; Friedland and Alford 1991). Other examples demonstrate that contradictions embedded in one "solution" can be exploited by opponents to alter outcomes at a later date. Gregory Hooks describes a shift in control of the United States Department of Agriculture between the 1930s and 1950s (Hooks 1990). The agency was at first run in top-down bureaucratic fashion and in line with New Deal progressive goals; by the 1950s it had been captured by the American Farm Bureau Federation. Among the reasons was that conflict between military procurement agencies and the USDA during World War II had left the department vulnerable to later cooptation. And, consider Margaret Weir's (1992) account of the evolution in U.S. labor market policy from the 1960s. Under the Johnson Administration, the goal of reducing structural unemployment ended up being pursued through the War on Poverty - a program that also, and quite visibly, was promoted in response to urban black protest. This move helped define unemployment policy as a social rather than an economic program, with the two lodged in separate institutional homes and enjoying different levels of political support. It also fatefully linked unemployment policy to race. Both features of this "solution" for unemployment gave conservatives leverage to curb proactive labor market policy in a later era. They could downsize programs for the poor without jeopardizing other economic policy-making, and they could play the race card to do so.

There is another way in which making actors the strategic pivots of historical narratives helps check deterministic accounts of locked-in paths. Howard Becker noted that sequences of events form coherent paths to the present only when looking backwards. Knowing where we ended up, we select singular routes from there to here, ignoring the myriad sequences that led, or might have led, in different directions (Becker 1994). Arranging past events into singular paths with a clear direction, however, is the work of ordinary people as well as "detached" observers. As some of those observers have noted, their own historical narratives have a similar character to the stories social actors tell to make sense of social change or to construct identities (Somers 1992; Carr 1997; Polletta 2006). But historical reversals highlight a further point that is more subversive for models of path dependency: when social actors change their interests, identities, or goals, they may rearrange past events, constructing new paths from the past towards the future. Scholars should show a corresponding appreciation for the mutability of paths and for the role of actors in reconfiguring them.

One way in which scholars can show such appreciation is to restore to their toolkit of narrative devices Marx's metaphor of new social possibilities developing in the womb of old regimes. In contrast to standard models of path dependency, it 
may be misleading to think in terms of distinct paths neatly separated by turning points. Instead, the second path may be traced back to before the critical juncture, with its constituent events occurring alongside those of the prior path. Whether this second path was actually conceived and nurtured by properties of the old regime - as implied by Marx's metaphor and as argued in his theory of capitalism - in retrospect it can be shown to have begun its run before the previous path expired. In his analysis of Spain's great reversal, Victor Pérez-Diaz (1993) shows that the restoration of liberal democracy took place rapidly and relatively smoothly because a democratic path was already in place. Well before the end of Franco's regime, workers had developed representative unions, the Church had begun to endorse pluralism, and a broad cross-section of Spaniards had come to accept western European political institutions as a legitimate model. The "new" democratic path on which Spain embarked after Franco's death thus began much earlier.

Pérez-Diaz, a "detached" observer, thus finds a democratic path running concurrently with Francoism. But as he hints, social actors themselves also do this work of charting new paths back into the past. He notes how many Spaniards invented a tradition of "democratic Spain" predating the civil war (Pérez-Diaz 1993:20-21). That invention illustrates a broader point on which various scholars agree: ordinary citizens as well as professional historians periodically reconfigure the past. Mustafa Emirbayer and Ann Mische point out that actors reconstruct their views of the past in response to changing interests or shifting identities in the present (Emirbayer and Mische 1998:968-969; see also Elster et al. 1998:296). William Sewell argues that such creative reconstruction is prompted by critical events. The storming of the Bastille gave birth to the modern notion of revolution as actors fused two, hitherto distinct cultural paths, one advancing ideals of popular sovereignty, the other representing traditions of popular violence (Sewell 1996a). Clemens draws attention to moments of dramatic change in which individual or collective "entrepreneurs" assemble pieces of the past in new ways, recombining "institutional legacies, network structures, and already available cultural schemas" (Clemens 2005:510). ${ }^{7}$ And students of "public history" describe how organized social groups sometimes rewrite narratives of the past to legitimate their interests and promote their goals (Molotch et al. 2000; Walton 2001).

Applied to successive regimes of problem solving, these arguments remind us that the stability of a given path is in part contingent on the cultural work of social actors as they selectively recall past events, participate in specific organizations, make use of particular resources, and define allies and enemies along certain lines. These things may change, creating new paths. ${ }^{8}$ Marshall Ganz examines a reversal in the fortunes of agricultural worker organizing in 1970s' California (Ganz 2000). Prior

\footnotetext{
${ }^{7}$ Abbott (2001:396) draws a biographical analogy, in which individuals rethink relationships in light of new knowledge ("he never really loved me"). For an extended fictional example, see Isabel Archer's reassessment of her husband and of her friend Madame Merle in Henry James' Portrait of a Lady.

${ }^{8}$ Even for a narrowly defined problem, such as how to maximize control over worker behavior or how to stabilize markets, there are likely to be different groups advocating rival solutions and justifying those proposals in part on the basis of narratives of past experience. The historical sociologist is likely to be interested in how one of those solutions and narratives "wins." But she should not assume in advance that this victory reflects the power of particular collective actors or that all alternatives are silenced until the next critical juncture.
} 
efforts to build labor solidarity and win recognition had consistently failed. Under Cesar Chavez, however, the UFW succeeded, and it did so in substantial part by redefining identities, appealing to farm workers on the basis of ethnic ties and national pride rather than on the basis of "class." Keynoting a different identity had the effect of activating new paths - making traditions of peasant theater, for example, relevant to labor organizing, together with long-standing symbols of Mexican heritage and rituals of Catholic devotion. The shift in identity also redefined farmworker organizing as part of a tradition of civil rights struggle, thereby connecting efforts to yet another preexisting path. And consistent with Clemens, the switch to a civil rights "schema" also actuated new resources and allies, including students and civil rights workers following trajectories of activism with roots older than the UFW.

Ganz's case study reminds us that actors are not free to make of the past whatever they wish. As students of collective memory note, the past can resist reinterpretation. The repertoires of events and "traditions" is not unlimited, and some collective memories are backed by powerful interests, embedded in durable institutions, preserved by public documents, and built into imposing monuments (Schudson 1992; Schwartz 1991; Spillman 1998). Much as the choices made at turning points are constrained by inherited frames, organizational settings, and social resources, so are the choices from among repertoires of tradition. However, actors do have some role in reconfiguring past paths as their identities and relations change in the present, and this helps loosen up path dependency's deterministic trajectories. Because actors and observers alike retrospectively rework and recombine paths, moreover, it is often a misleading simplification to distinguish periods on the basis of distinct paths separated by critical junctures. ${ }^{9}$

\section{Back to San Francisco}

How does this alternative to path dependency help construct a richer narrative of San Francisco's reversal in business class formation? ${ }^{10}$ The early-20th-century status quo can be seen as one viable solution for problems of industrial order. Employers relied on industry-wide collective bargaining to take wages out of competition, regulate conflict, and provide a stability that fractious employers acting on their own could not. Although rare in the United States, ${ }^{11}$ this "variety of capitalism" (Hall and Soskice 2001) had counterparts in Europe. The open shop that employers consolidated in the early 1920 s was a quite different path to industrial order, requiring both individual and collective employer vigilance to keep unions at bay, and usually involving alternative, in-house mechanisms for handling conflict. ${ }^{12}$

\footnotetext{
${ }^{9}$ Orren and Skowronek (2004) reach a similar conclusion on the basis of their observation that responses to crises are themselves shaped by the past. "The problem becomes how to distinguish between paths and junctures, between the kind of change that counts as reinforcing and the kind that counts as redirecting” (p. 103). ${ }^{10}$ The following draws on Haydu (2008).

${ }^{11}$ For a comparison of U.S. and British metal working in which the "British" approach resembles San Francisco, see Haydu (1988). For some other "exceptional” U.S. cases, see Johnson (1979) on coal, Stern (1994) on pottery, and Klug (1993) on stove manufacturing.

12 These mechanisms might include company unions, more rule-bound discipline, or the palliatives of welfare capitalism.
} 
In explaining the reversal of collective bargaining in San Francisco, it is possible to identify 1916 as a turning point. It was in this year that San Francisco's Chamber of Commerce formally endorsed the open shop and spearheaded a successful drive for municipal restrictions on unions' right to picket. Two important events occasioned this about-face. One was an unusually disruptive and "illegal" (violating an existing contract) waterfront strike; the second was the infamous bombing at the Preparedness Day parade. These events could be the focal point of a narrative of path dependency, in which serendipitous happenings, unpredictable on the basis of prior history, steered developments onto a new path, a path then reinforced by government policies (the anti-picketing ordinance), organizational practices (the Chamber of Commerce's support for the open shop), and ancillary investments (in management techniques designed to keep unions out). But a richer narrative would, to begin with, recount how vulnerabilities in the prior "solution" shaped the critical juncture itself. The regime of trade agreements depended heavily on union officials controlling their own members, and it involved a corresponding rhetorical emphasis on the need for union "responsibility." Wartime conditions - including the combination of rapid inflation and workers' enhanced leverage vis-à-vis employers - made it increasingly difficult to hold the rank and file to the terms of contracts and, once the U.S. entered the war, to government awards. The "customary" value assigned to responsible union behavior, moreover, both focused employer attention on this issue and gave them a ready-made language to denounce irresponsible labor action.

Explaining San Francisco's switch from trade agreement to open shop and from employer fragmentation to solidarity also requires attention to trajectories that predate the crisis of 1916. One such trajectory involved class relations. The direct involvement of organized labor in local politics, notably during the Union Labor Party's control over municipal government between 1901 and 1911, was a crucial bulwark for trade agreements. Labor's political power deprived employers of a customary weapon against unions (city police) and helped divide capital between those willing to cooperate and an open-shop minority. The collapse of the ULP amidst political scandal, and organized labor's decision in 1911 to abandon independent electoral action in favor of participation in a progressive coalition, created new opportunities for capital. A second trajectory involved business organization. In other cities, the involvement of merchants and manufacturers in civic organizations supported class-wide solidarity. Such organizations helped overcome competitive rivalries and differences in trade interests, and they fostered a language of classless civic uplift that could be turned against unions. In San Francisco, local manufacturers in the 1890s and 1900s were much less involved in organizations of this kind. That began to change after the 1906 earthquake, with business elites coming together less for immediate rebuilding than to plan for the 1915 celebration of the city's rebirth, the Panama Pacific International Exhibition. This organizational trajectory gained speed in 1911 with the merger of several business organizations into a revamped and expanded Chamber of Commerce. Past paths thus provided key opportunities and resources to businessmen responding to critical events in 1916.

Problem-solving narratives, finally, highlight the social actors who bring these paths together. One legacy of organizational changes was to give the top officers of the Chamber of Commerce an influence that prior business leaders had not enjoyed. 
And the men who occupied those offices were veterans of earlier, unsuccessful openshop drives. First among them was Chamber of Commerce President Frederick Koster and his allies on an executive body known as the "Law and Order Committee." These men proved skillful at exploiting opportunities and keeping the business troops in line. One such opportunity, of course, was the waterfront strike, with its breach of contract, its violence, and its stifling of commercial activity. The strike provided one major focus for Chamber of Commerce demands for law and order. Only a month later, Koster skillfully framed the Preparedness Day bombing as the continuation of a single path running from union power through the waterfront strike. "Recent disturbances upon the water front were accompanied by violence. Intimidation was practiced on merchants and their employees and an intolerable situation resulted.... This spirit of lawlessness in the community logically terminated in the damnable bomb outrage on Saturday" (San Francisco Examiner, July 25, 1916). In taking advantage of these events, Koster reconstructed the past in another way, popularizing a narrative in which San Francisco's loss of economic standing to rival west coast cities followed inevitably from labor's stranglehold over local commerce and industry. The narrative extended from this inglorious past to a bright future, in which public-spirited businessmen freed the city from the "industrial and political disease" of union control (quoted in Knight 1960:305). That bright future was finally realized in the post-World War I open-shop drive.

\section{Conclusion}

For the purpose of analyzing successive historical periods - as dramatized in this paper by historical reversals - narratives of path dependency and reiterated problem solving share several virtues. They strike a judicious balance between causal generalization, insensitive to historical context, and an idiographic refusal to make connections between one historical period and another. They incorporate events into explanatory accounts. And they point to specific mechanisms through which the causal influence of past events is conveyed to the present.

As we all know from family gatherings, good stories are not necessarily true stories. Constructing narratives in the form of path dependency or reiterated problem solving is no guarantee of a compelling explanation. But narratives are more than the stories we tell our readers, selecting and organizing evidence we have found into what we hope is a persuasive explanatory account. They are also heuristic devices that guide our search for evidence, advising us where to look. Alternative narratives of institutional change point our research to different phenomena. Orren and Skowronek, for example, offer a narrative of "intercurrence" which calls attention to frictions among institutional components created at different times or for different purposes. Those frictions, Orren and Skowronek argue, help us understand subsequent patterns of change. The narratives of path dependency and reiterated problem solving, similarly, guide research on institutional change in particular ways. Path dependency has us look for exogenous shocks. Reiterated problem solving tells us to track actors pursuing customary goals under new conditions. None of these narrative models leads unerringly to sound explanations. But in addition to directing our research focus, they provide a different kind of legitimacy for explanatory 
accounts. Positivists provide the counterpoint here. Quite apart from their other rules for evaluating causal claims, they offer the more aesthetic rule that parsimonious theories are preferable to complex ones.

As both research guide and legitimating principle, reiterated problem solving is a more productive metaphor than path dependency when the task is to both compare time periods and combine them into more encompassing sequences. It offers a better way to integrate historical determinism and eventful junctures; it makes it easier to narrate the convergence of multiple causal sequences; it identifies a wider range of mechanisms through which past events and outcomes shape later ones; and it avoids path dependency's depiction of historical paths as singular and irreversible. It accomplishes these methodological goals in part by making social actors the historical pivots that link "cases" of problem solving. Reconstructing the problemsolvers' understandings and choices - how they make use of the past - enables us to account for trajectories across multiple periods. It also calls attention to the overlapping and mutable character of paths. And in all these ways, the metaphor of reiterated problem solving goes well beyond path dependency in justifying complex historical explanations over parsimonious ones.

Acknowledgments Akos Rona-Tas, Gershon Shafir, John Skrentny, and Carlos Waisman alerted me to studies of historical reversals I might otherwise have missed. Lis Clemens, Jack Goldstone, Larry Isaac, Isaac Martin, Chris Rhomberg, John Walton, Mayer Zald, an anonymous Theory and Society reviewer, and especially Kathy Mooney, pushed me to clarify arguments I might otherwise have fudged. My thanks to them all.

Open Access This article is distributed under the terms of the Creative Commons Attribution Noncommercial License which permits any noncommercial use, distribution, and reproduction in any medium, provided the original author(s) and source are credited.

\section{References}

Abbott, A. (1992). From causes to events: notes on narrative positivism. Sociological Methods and Research, 20(4), 428-455.

Abbott, A. (2001). Time matters: On theory and method. Chicago: University of Chicago Press.

Abraham, D. (1981). The collapse of the Weimar Republic: Political economy and crisis. Princeton: Princeton University Press.

Arthur, W. B. (1988). Self-reinforcing mechanisms in economics. In P. W. Anderson, K. J. Arrow \& D. Pines (Eds.), The economy as an evolving complex system (pp. 9-31). Redwood City: AddisonWesley.

Arthur, W. B. (1994). Increasing returns and path dependence in the economy. Ann Arbor: University of Michigan.

Becker, H. S. (1994). "Foi Por Acaso": conceptualizing coincidence. The Sociological Quarterly, 35(2), 183-194.

Bendix, R. (1978). Kings or people: Power and the mandate to rule. Berkeley: University of California Press.

Bennett, A., \& Elman, C. (2006). Complex causal relations and case study methods: The example of path dependence. Political Analysis, 14, 250-267.

Bridges, A. (2000). Path dependence, sequence, history, theory. Studies in American Political Development, 14, 109-112.

Burawoy, M. (1979). Manufacturing consent: Changes in the labor process under monopoly capitalism. Chicago: University of Chicago Press.

Carr, D. (1997). Narrative and the real world: An argument for continuity. In L. P. Hinchman \& S. K. Hinchman (Eds.), Memory, identity, community: The idea of narrative in the human sciences (pp. 725). Albany: State University of New York Press. 
Clemens, E. S. (1997). The people's lobby: Organizational innovation and the rise of interest group politics in the United States, 1890-1925. Chicago: University of Chicago Press.

Clemens, E. S. (2005). Afterword: Logics of history? Agency, multiplicity, and incoherence in the explanation of change. In J. Adams, E. S. Clemens \& A. S. Orloff (Eds.), Remaking modernity: Politics, history, and sociology (pp. 493-515). Durham: Duke University Press.

Crouch, C., \& Farrell, H. (2004). Breaking the path of institutional development? Alternatives to the new determinism. Rationality and Society, 16(1), 5-43.

David, P. A. (1986). Understanding the economics of QWERTY: The necessity of history. In W. N. Parker (Ed.), Economic history and the modern economist (pp. 30-49). Oxford: Blackwell.

Einolf, C. J. (2007). The fall and rise of torture: a comparative and historical analysis. Sociological Theory, 25(2), 101-121.

Elster, J., Offe, C., \& Preuss, U. K. (1998). Institutional design in post-communist societies: Rebuilding the ship at sea. Cambridge: Cambridge University Press.

Emirbayer, M., \& Mische, A. (1998). What is agency? American Journal of Sociology, 103(4), 962-1023.

Ertman, T. (1997). Birth of the Leviathan: Building states and regimes in medieval and early modern Europe. New York: Cambridge University Press.

Feldman, G. D. (1966). Army, industry and labor in Germany, 1914-1918. Princeton: Princeton University Press.

Foran, J. (2005). Taking power: On the origins of third world revolutions. New York: Cambridge University Press.

Forbath, W. E. (1991). Law and the shaping of the American labor movement. Cambridge: Harvard University Press.

Fredrickson, G. M. (1988). The arrogance of race: Historical perspectives on slavery, racism, and social inequality. Middletown: Wesleyan University Press.

Fredrickson, G. M. (1997). The comparative imagination: On the history of racism, nationalism, and social movements. Berkeley: University of California Press.

Friedland, R., \& Alford, R. R. (1991). Bringing society back in: Symbols, practices, and institutional contradictions. In W. Powell \& P. DiMaggio (Eds.), The New Institutionalism in Organizational Analysis (pp. 232-263). Chicago: University of Chicago Press.

Ganz, M. (2000). Resources and resourcefulness: strategic capacity in the unionization of California agriculture, 1959-1966. American Journal of Sociology, 105(4), 1003-1062.

Gerteis, J. (2007). Class and the color line: Interracial class coalition in the knights of labor and the populist movement. Durham: Duke University Press.

Goldstone, J. A. (1998). Initial conditions, general laws, path dependence, and explanation in historical sociology. American Journal of Sociology, 104(3), 829-845.

Gotham, K. F., \& Staples, W. G. (1996). Narrative analysis and the new historical sociology. The Sociological Quarterly, 37(3), 481-501.

Griffin, L. J. (1993). Narrative, event-structure analysis, and causal interpretation in historical sociology. American Journal of Sociology, 98(5), 1094-1133.

Hall, P. A., \& Soskice, D. (2001). An introduction to varieties of capitalism. In P. A. Hall \& D. Soskice (Eds.), Varieties of capitalism: The institutional foundation of comparative advantage (pp. 1-68). Oxford: Oxford University Press.

Hattam, V. C. (1993). Labor visions and state power: The origins of business unionism in the United States. Princeton: Princeton University Press.

Haydu, J. (1988). Trade agreement vs. open shop: employers' choices before WWI. Industrial Relations, 28(2), 159-173.

Haydu, J. (1997). Making American industry safe for democracy: Comparative perspectives on the state and employee representation in the Era of World War I. Urbana: University of Illinois Press.

Haydu, J. (1998). Making use of the past: time periods as cases to compare and as sequences of problem solving. American Journal of Sociology, 104(2), 339-371.

Haydu, J. (2008). Citizen employers: Business communities and labor in Cincinnati and San Francisco, 1870-1916. Ithaca: Cornell University Press.

Haydu, J., \& Lee, C. (2004). Model employers and good government in the late 19th and late 20th centuries. Sociological Forum, 19(2), 177-202.

Hooks, G. (1990). From an autonomous to a captured state agency: the decline of the new deal in agriculture. American Sociological Review, 55, 29-43.

Isaac, L. W., \& Griffin, L. J. (1989). Ahistoricism in time-series analysis of historical process: critique, redirection, and illustrations from U.S. labor history. American Sociological Review, 54 (6), 873-890. 
Johnson, J. P. (1979). The politics of soft coal: The bituminous industry from World War I through the New Deal. Urbana: University of Illinois Press.

Jones, L. E. (1988). German liberalism and the Dissolution of the Weimar Party System, 1918-1933. Chapel Hill: The University of North Carolina.

Kimeldorf, H. (1988). Reds or rackets? The making of radical and conservative unions on the waterfront. Berkeley: University of California Press.

Kiser, E., \& Hechter, M. (1991). The role of general theory in comparative-historical sociology. American Journal of Sociology, 97(1), 1-30.

Klug, T. A. (1993). The Roots of the Open Shop: Employers, Trade Unions, and Craft Labor Markets in Detroit, 1859-1907 [Ph. D. dissertation, Wayne State University].

Knight, R. E. L. (1960). Industrial relations in the San Francisco Bay area, 1900-1918. Berkeley: University of California Press.

Mahoney, J. (2000). Path dependence in historical sociology. Theory and Society, 29(4), 507-548.

Mahoney, J. (2001). The legacies of liberalism: Path dependence and political regimes in Central America. Baltimore: Johns Hopkins University Press.

Mahoney, J. (2004). Comparative-historical methodology. Annual Review of Sociology, 20, 81-101.

Maier, C. S. (1975). Recasting Bourgeois Europe: Stabilization in France, Germany, and Italy in the Decade after World War I. Princeton: Princeton University Press.

Martin, I. W. (2008). The permanent tax revolt: How the property tax transformed American politics. Stanford: Stanford University Press.

McDaniel, T. (1991). Autocracy, modernization, and revolution in Russian and Iran. Princeton: Princeton University Press.

Miller, P. (1998). Transformations of Patriarchy in the West, 1500-1900. Bloomington: Indiana University Press.

Molotch, H., Freudenburg, W., \& Paulsen, K. E. (2000). History repeats itself, but how? City character, urban tradition, and the accomplishment of place. American Sociological Review, 65(6), 791-823.

North, D. C. (1990). Institutions, institutional change and economic performance. Cambridge: Cambridge University Press.

Orloff, A. S. (1993). The politics of pensions: A comparative analysis of Britain, Canada, and the United States, 1880-1940. Madison: University of Wisconsin Press.

Orren, K., \& Skowronek, S. (2004). The search for American political development. New York: Cambridge University Press.

Paige, J. M. (1997). Coffee and power: Revolution and the rise of democracy in Central America. Cambridge: Harvard University Press.

Pérez-Diaz, V. M. (1993). The return of civil society: The emergence of democratic Spain. Cambridge: Harvard University Press.

Pierson, P. (1994). Dismantling the welfare state?: Reagan, thatcher, and the politics of retrenchment. New York: Cambridge University Press.

Pierson, P. (2004). Politics in time: History, institutions, and social analysis. Princeton: Princeton University Press.

Piore, M. J., \& Sabel, C. F. (1984). The second industrial divide: Possibilities for prosperity. New York: Basic Books.

Polletta, F. (2006). It was like a fever: Storytelling in protest and politics. Chicago: University of Chicago Press.

Putnam, R. D. (1993). Making democracy work: Civic traditions in modern Italy. Princeton: Princeton University Press.

Quadagno, J., \& Knapp, S. J. (1992). Have historical sociologists forsaken theory? Thoughts on the history/theory relationship. Sociological Methods and Research, 20(4), 481-507.

Reskin, B. F., \& Roos, P. A. (1990). Job queues, gender queues: Explaining women's inroads into male occupations. Philadelphia: Temple University Press.

Rhomberg, C. (2004). No there there: Race, class, and political community in Oakland. Berkeley: University of California Press.

Sabetti, F. (1996). Path dependency and civic culture: some lessons from Italy about interpreting social experiments. Politics and Society, 24(1), 19-44.

Schneiberg, M. (2007). What's on the path? Path dependence, organizational diversity and the problem of institutional change in the US Economy, 1900-1950. Socio-Economic Review, 5, 47-80.

Schudson, M. (1992). Watergate in American memory: How we remember, forget, and reconstruct the past. New York: Basic Books.

Schwartz, B. (1991). Social change and collective memory: the democratization of George Washington. American Sociological Review, 56(2), 221-236. 
Sewell, W. H., Jr. (1996a). Historical events as transformations of structures: inventing revolution at the Bastille. Theory and Society, 25(6), 841-881.

Sewell, W. H., Jr. (1996b). Three temporalities: Toward an eventful sociology. In T. J. McDonald (Ed.), The historic turn in the human sciences (pp. 245-280). Ann Arbor: University of Michigan Press.

Sewell, W. H., Jr. (2005). Logics of history: Social theory and social transformation. Chicago: University of Chicago Press.

Somers, M. R. (1992). Narrativity, narrative identity, and social action: rethinking english working-class formation. Social Science History, 16(4), 591-630.

Somers, M. R. (1998). 'We're no angels': realism, rational choice, and relationality in social science. American Journal of Sociology, 104(3), 722-784.

Spillman, L. (1998). When do collective memories last? Social Science History, 22(4), 445-477.

Starr, P. (1990). The new life of the liberal state: Privatization and the restructuring of state-society relations. In E. N. Suleiman \& J. Waterbury (Eds.), The political economy of public sector reform and privatization (pp. 22-54). Boulder: Westview.

Steinmo, S. (1993). Taxation and democracy: Swedish, British, and American approaches to financing the modern state. New Haven: Yale University Press.

Stern, M. J. (1994). The pottery industry of trenton: A skilled trade in transition, 1850-1929. New Brunswick: Rutgers University Press.

Thelen, K. (1999). Historical institutionalism in comparative politics. Annual Review of Political Science, 2, 369-404.

Thelen, K. (2004). How institutions evolve: The political economy of skills in Germany, Britain, the United States, and Japan. Cambridge: Cambridge University Press.

Traugott, M. (1985). Armies of the poor: Determinants of working-class participation in the Parisian insurrection of June 1848. Princeton: Princeton University Press.

Voss, K. (1993). The making of American exceptionalism: The knights of labor and class formation in the nineteenth century. Ithaca: Cornell University Press.

Waisman, C. H. (1987). Reversal of development in Argentina: Postwar counterrevolutionary policies and their structural consequences. Princeton: Princeton University Press.

Walton, J. (1992). Western times and water wars: State, culture, and rebellion in California. Berkeley: University of California Press.

Walton, J. (2001). Collective memory and action: The production of California history. Davis: University of California.

Weir, M. (1992). Politics and jobs: The boundaries of employment policy in the United States. Princeton: Princeton University Press.

Jeffrey Haydu is Professor of Sociology at the University of California, San Diego. He is the author of Between Craft and Class (University of California Press, 1988), Making American Industry Safe for Democracy (University of Illinois Press, 1997), and Citizen Employers (Cornell University Press, 2008). $\mathrm{He}$ is currently studying food-related protest movements in historical and comparative perspective. 